\title{
Losy nauczycieli Wielkopolski wschodniej w czasie II wojny światowej w świetle zapisów kronik szkolnych. Wprowadzenie do problematyki
}

\begin{abstract}
The fate of teachers in Eastern Greater Poland during World War II based on school chronicle records. Introduction to the subject

School chronicles are an important but sometimes underestimated source of information for the history of education. The difficulties with their use result from their dispersion, lack of availability and subjective nature. However, despite their subjectivity, they can provide extremely interesting information, e.g. on the biographies of individual educators. This article focuses on the war fate of school teachers in the Eastern Greater Poland. Almost all of them lost their jobs as a result of the closure of schools. Many were deported to the General Government or to forced labour in Germany. Those who stayed undertook off-an-on work or jobs that had nothing to do with the teaching profession. Despite the threat to their lives, some of them were also engaged in secret teaching. Unfortunately, there were also those who decided to collaborate with the German occupier. The research included in this article should be considered an introduction to research in this source area.
\end{abstract}

Keywords: school chronicle, World War II, teachers, fate, Eastern Greater Poland

Kroniki szkolne pozostają nadal źródłem, które nie do końca jest doceniane przez badaczy nie tylko dziejów oświaty, ale także i innych dyscyplin. Najprawdopodobniej wynika to z kilku przyczyn. Pierwszą z nich z pewnością jest rozproszenie tych dokumentów po różnych szkołach i placówkach oświatowych, drugą zaś ich subiektywny przekaz. Tymczasem, mimo tej subiektywności są niezwykle ciekawym źródłem i do dziejów oświaty, i do odtwarzania biografii poszczególnych nauczycieli ${ }^{1}$. Biorąc pod

${ }^{1}$ Zob. na przykład: P. Gołdyn, Kronika szkolna jako nie(d)ocenione źródło do dziejów oświaty regionalnej, w: Badania historyczne w pedagogice. Konteksty źródłowe, red. W. Szulakiewicz, Toruń 2015, s. 111-131; idem: Watki biograficzne nauczycieli w kronikach szkolnych. Przykład Wielkopolski wschodniej, w: Przedmiot, źródła i metody badań w biografi, red. R. Skrzyniarz, L. Dziaczkowska, D. Opozda, Lublin 2016, s. 309-322; 
uwagę region Wielkopolski wschodniej², losy nauczycieli w czasie II wojny światowej były raczej odtwarzane, ściślej mówiąc zapisywane w kronikach już po zakończeniu działań wojennych. Trudno było robić to w czasie okupacji, choćby ze względu na fakt, że szkoły były zamknięte a nauczyciele usunięci z posad. Niniejsze rozważania stanowią próbę wprowadzenia do problematyki, której głównym przedmiotem są nauczyciele i ich losy w czasie II wojny światowej. Głównym zaś źródłem pozostają kroniki szkolne. Poruszane tu wątki dotyczyć będą losów nauczycieli, którzy w wyniku wojny stracili posady, których wysiedlono do innych części Polski. Wielu z nich również poniosło śmierć bądź to w walce, bądź w obozach koncentracyjnych.

Przed wybuchem wojny kierownikiem szkoły w Białej Panieńskiej był Franciszek Stanowski. W momencie napadu Niemców na Polskę wsiadł on na rower i podobnie jak większość mieszkańców zachodnich części Ojczyzny udał się w kierunku Warszawy. Po kapitulacji stolicy i wezwaniu okupantów wrócił jednakże do miejsca pracy. Tak swój powrót i pierwszych kilka dni opisał na łamach kroniki: Po dwóch tygodniach tułaczki wrócit spod Warszawy kier. szkoły Stankowski Fr. na dawne stanowisko, ale jeszcze $w$ ciagu kilku tygodni nie mógt $w$ domu przebywać, bo ciagłe skargi miejscowych Niemców sprowadzaty kilkukrotnie żandarmerię polowa $w$ petnym uzbrojeniu, ażeby go zabrać. Będac ostatni raz przeszukali cała cegielnię (bo tam przeważnie z rodzina przebywat), a nie znalazłszy kierownika przyjechali koło szkoły, gdzie wisiał emaliowany orzeł polski, dali do niego kilkanaście strzałów, zdemolowali go zupetnie. Niestety, po kilkurazowym przeszukaniu powrócili z niczym do Grodźca, tymczasem żandarmeria polowa wyjechała i wszystko minęto ${ }^{3}$.

Kierownik mógł wrócić do pracy. Razem z nim pracowała także jego żona oraz Antoni Ratajski, były polski oficer. Zastąpił on dwoje innych nauczycieli - Zytę Chylińską i Antoniego Kubiaka - którzy wyjechali z Białej Panieńskiej i już nie wrócili. Wszyscy ci nauczyciele, podobnie jak inni w Kraju Warty, pracowali tylko do marca 1940. Wtedy to zamknięto wszystkie polskie szkoły. Przed Niemcami musiała ukrywać się również nauczycielka z Grzymiszewa. Urszula Osmakówna była podejrzewana, a nawet oskarżana o działalność na szkodę państwa niemieckiego ${ }^{4}$.

O swojej ucieczce $\mathrm{z}$ miejsca zamieszkania w obawie przed Niemcami na łamach kroniki pisał także nauczyciel ze szkoły w Kucharach Kościelnych: Piszący tę kronikę po otrzymaniu zwolnienia [z pracy w szkole] ulotnit się z miejsca zamieszkania do powiatu tureckiego i dzięki temu unikną obozu. Nie minęto go jednak wywiezienie do pracy, ale tylko do Poznania, gdzie pracowat jako robotnik przy robotach ziemnych $w$ charakterze betoniarza ${ }^{5}$.

Przed Niemcami w głąb Polski uciekał również Lech Wojtkowski - nauczyciel z Tuliszkowa, który zginął od kuli z samolotu. Prawdopodobnie stało się to w czasie ewaku-

\footnotetext{
2 Określenie Wielkopolska wschodnia jest terminem sztucznie wykreowanym, na potrzeby niniejszych rozważań. W tym konkretnym przypadku obejmuje historyczne powiaty: kolski, koniński i turecki z lat 1931-1950.

${ }^{3}$ Kronika Szkoły Podstawowej w Białej Panieńskiej. cz. II, bp.

${ }^{4}$ Kronika Szkoły w Grzymiszewie za lata 1945-1951, bp.

${ }^{5}$ Kronika szkoły w Kucharach Kościelnych za lata 1949-1992, bp.
} 
acji w kierunku Warszawy, był bowiem inwalidą wojennym z roku 1920, więc nie brał raczej udziału w działaniach zbrojnych ${ }^{6}$.

Po krótkiej zawierusze wojennej, 26 września 1939 r. niemieckie władze okupacyjne nakazały rejestrowanie się nauczycieli w inspektoracie szkolnym. Dla zachowania pozorów pozwolono wznowić naukę, zatrudniając w szkołach polskich nauczycieli. Przykładowo w Biskupicach lekcji udzielało małżeństwo Rederów i Katarzyna Tyma ${ }^{7}$ Mimo zgody na powrót dzieci i nauczycieli do szkoły praca nie należała do najłatwiejszych. Usuwano bowiem systematycznie z programów przedmioty typowo polskie i nakazywano wprowadzać do nauki język niemiecki. Poza tym o prowadzeniu normalnej nauki nie mogło być mowy: nauczycielstwo narażone było na bezustanne szykany, żyło w ciagtym strachu i obawie przed wywiezieniem na roboty, wywłaszczeniem czy tė więzieniem. Nauczycielstwo narażone było więcej na prześladowanie niż reszta ludności $i^{8}$.

Po ponownym uruchomieniu szkół w październiku i listopadzie 1939 r. wprowadzono jako obowiązkowy język niemiecki. Do nauki tego przedmiotu brakowało nauczycieli niemieckich, więc próbowano wykorzystać Polaków. Wobec powyższego na przykład w Zagórowie urządzono im trzydziestogodzinne szkolenie. Odbywało się ono trzy razy w tygodniu po trzy godziny. Był to więc dość intensywny kurs. Zagórowscy nauczyciele uczeni byli na tym kursie przez miejscowych Niemców - doktora Hugona Breade i pastora Aleksandra Grossa9.

Szkoły funkcjonowały zaledwie kilka miesięcy, po czym zakazano nauczania dzieci polskich. Zamknięcie szkół w marcu 1940 r. pozbawiło nauczycieli możliwości pracy i zarabiania. Imali się różnych zajęć. Poza tym pojawiło się przygnębienie, obawy o życie swoje i swoich rodzin. Tak opisano sytuację nauczycieli w Kłodawie po zamknięciu szkół: Nauczycielstwo po uwolnieniu z aresztu wegetowało dtugie miesiące, wysprzedając co kto mógt. Niektórzy uczyli tajnie, lecz było to przedsięwzięcie bardzo niebezpieczne, gdyż żandarmeria i policja pomocnicza pilnie śledziła. Gdy „,Abreitsamt” wszystkich bez wyjątku Polaków ująt w swa ewidencję, nauczycielstwo zmuszone koniecznościa materialna oraz obawa przed represjami zaciagało się do pracy $w$ urzędach i przedsiębiorstwach niemieckich ${ }^{10}$.

Nauczycielka H. Sobczakowa z Kuchar Kościelnych pracowała w kamieniołomach w pobliskiej Święci ${ }^{11}$. Swoje zajęcia w czasie okupacji na kartach kroniki opisał również kierownik szkoły w Modle Królewskiej. Pisał: Ja ze swej strony zacząłem pracować jako pomocnik w pracach rolnych u Roz. Kwiecińskiej w Modle Król. Tu rodzaj pracy najwięcej dawat mi możność utrzymywania kontaktu z tut. ludnościa, która z wolna przygotowywałem i hartowałem do znoszenia ciężkiego jarzma niewoli niem. W rozmowach pouczałem jak postępować, aby lekkomyślnie i częstokroć bezcelowo nie narażać siebie

\footnotetext{
${ }^{6}$ Kronika szkoły w Tuliszkowie za lata 1945-1959, bp.

7 Kronika szkoły w Biskupicach za lata 1926-1973, bp.

${ }^{8}$ Kronika szkoły w Budzisławiu Kościelnym za lata 1945-1994, bp.

9 Kronika szkoły w Zagórowie za lata 1945-1983, s. 14.

10 Kronika szkoły w Kłodawie za lata 1931-1951, bp.

${ }^{11}$ Kronika szkoły w Kucharach Kościelnych za lata 1949-1992, bp.
} 
i swoich najbliższych na zsyłkę do karnych obozów koncentracyjnych z jednoznacznym zachowaniem godności i poczucia narodowego. Zadanie to spetnitem przy każdej sposob$n o s ́ c i^{12}$. Na początku grudnia 1940 r. wyjechał do Kramska, gdzie do końca wojny pracował jako pomocnik młynarza. Uchroniło go to przed wysiedleniem lub wywózką do Niemiec na roboty.

Ten krótki okres funkcjonowania polskich szkół, do początków wiosny 1940 nazywano często parodią nauki. Jednakże, jak zauważył kierownik szkoły w Kotuni miało to swoje pozytywne strony. Otrzymana przez nauczycieli trzymiesięczna wypłata pozwoliła przetrwać im jakiś czas w trudnych warunkach materialnych ${ }^{13}$. Trzeba jednakże zauważyć, że wypłacone pobory choć były niskie traktowane były w stosunku 1 złoty = 1 marka. Podczas gdy w innych okolicznościach walutę polską wymieniano na niemiecką W stosunku 2:14.

Praca pod presją nie należała do najłatwiejszych. Nauczyciele obawiali się przede wszystkim aresztowań, do których dochodziło bardzo często. Jeden z takich przypadków opisany został w kronice Szkoły Powszechnej w Brdowie: W dniu 2 listopada [1939] kier. szkoty otrzymat nakaz od milicji niemieckiej zwołania zebrania nauczycielskiego. Podczas tego zebrania zaaresztowano nas $i$ wywieziono do Izbicy, a wieczorem do Koła. Nauczycielki siedziały $w$ klasztorze, nauczyciele $w$ więzieniu kolskim. Po kilku tygodniowym zamknięciu grono powróciło do domu ${ }^{15}$. Aresztowania te objęły nie tylko nauczycieli brdowskiej szkoły, ale prawdopodobnie wszystkich szkół na terenie powiatu kolskiego. Wspomina o nim także kierownik i nauczyciel szkoły w Dzierawach - Ignacy Ziębowicz $^{16}$. Z kroniki szkoły powszechnej w Kłodawie wynikają dodatkowe fakty tego aresztowania. Otóż potwierdził się fakt przetrzymywania kobiet w klasztorze, ale dodatkowym elementem jest fakt, że stłoczono je w liczbie sześćdziesięciu w jednej sali, w okropnych warunkach sanitarnych. Przetrzymywano je jednakże tylko tydzień. Mężczyźni zwolnienie zostali dopiero po trzech tygodniach. Przy zwalnianiu z aresztu zakazano kategorycznie pod karą śmierci nauczania dzieci i młodzieży ${ }^{17}$.

O tym, kto będzie zatrudniony w szkole w okresie od października 1939 r. decydowali przede wszystkim Niemcy. Choć w kronice szkoły w Kotuni pojawił się dość enigmatyczny zapis: Dopiero pod koniec października powiatowe władze niemieckie rejestruja nauczycieli i zawiadamiaja kto będzie zatrudniony w szkolnictwie. Oczywiście nie wszyscy, ci, co do których mieli urazę Ukraińcy, jak Pohorecki i inni, nie moga liczyć na zatrudnienie ${ }^{18}$. Skąd Ukraińcy? Otóż prawdopodobne są dwie przyczyny. Pierwszą $\mathrm{z}$ nich jest fakt, że po wojnie polsko-bolszewickiej wielu z nich osiedliło się na tych terenach po zwolnieniu ich z obozu w Strzałkowie. Drugą, że w szkolnictwie powszech-

\footnotetext{
12 Kronika szkoły w Modle Królewskiej za lata 1912-1948, bp.

13 Kronika szkoły w Kotuni za lata 1945-1978, bp.

14 Kronika szkoły w Zagórowie za lata 1945-1983, s. 15.

15 Kronika szkoły w Brodowie za lata 1945-1996, bp.

${ }^{16}$ Kronika szkoły w Dzierawach za lata 1931-1976, s. 38.

17 Kronika szkoły w Kłodawie za lata 1931-1951, bp.

${ }^{18}$ Kronika szkoły w Kotuni za lata 1945-1978, bp.
} 
nym Wielkopolski wschodniej zdarzało się, iż nauczycielami, a nawet kierownikami szkół byli Ukraińcy, jak np. w Sławsku ${ }^{19}$.

Wielu nauczycieli zostało wysłanych na roboty przymusowe. Według zapisów kroniki w Biskupicach, taki los spotkał tamtejszych pedagogów ${ }^{20}$. Podobnie było z nauczycielami z Budzisławia Kościelnego, których wywieziono do Generalnego Gubernatorstwa, pozbawiając ich dotychczasowej własności, pozostawiając tylko z niewielkim bagażem²1. Taki sam los spotkał nauczycieli w Ciążeniu. Już 11 lutego 1940 r. rodzina Kominków (dwoje nauczycieli) została wysiedlona do GG, natomiast druga rodzina (Gesslerów) również dwoje nauczycieli - sama wyjechała do Generalnego Gubernatorstwa do swoich krewnych. Kolejne wysiedlenia miały miejsce w maju 1940. Wtedy to 45 rodzin, w tym rodzinę kierownika szkoły wywłaszczono ze wszystkiego, co posiadali, nawet z bielizny, ubrań, pościeli z zamiarem wywiezienia do Niemiec na przymusowe roboty. Najpierw wysłano ich do Koła, gdzie przeszli badania lekarskie. Nie wszyscy jednakże nadawali się do ciężkiej pracy na roli. Należał do nich kierownik szkoły w Ciążeniu, którego wraz z żoną wysłano do gminy Rzgów, gdzie spędził całą wojnę ${ }^{22}$.

Wywieziono również nauczycieli ze szkoły w Golinie, a przynajmniej ich część (Jan i Jadwiga Misiakowie i Leokadia Kwiatkowska). Zostali przeniesieni wraz z innymi mieszkańcami do Generalnego Gubernatorstwa. Kronika szkolna opisuje to w sposób niezwykle dramatyczny: Musza zostawić wszystko, zabieraja tylko mały tłomoczek. Pędzeni do stacji kolejowej Spławie z dziećmi na rękach podczas bardzo dużego mrozu². Zimą 1940 r. wysiedlono z Kotuni rodzinę nauczycielską - Kominków. Niestety z zapisu kronikarskiego nie znane jest miejsce, w które zostali skierowani ${ }^{24}$.

W lutym, 13 dokonano wysiedlenia części mieszkańców z gminy Kramsk. Jak podaje zapis w kronice byli to przede wszystkim nauczyciele. A wyglądało to mniej więcej tak: Nie pozwalają nic zabrać ze soba, tylko na osobę 100 zł, resztę gotówki oddać, złoto i srebro oddać, na osobę wziać 1 jasiek i 1 koc oraz jedzenie na 10 dni, reszta wszystko zostaje, a mieszkania pieczętują. Po potudniu odwoża nas sańmi do Konina ${ }^{25}$.

Nauczycieli ze szkoły w Lubstowie również wysiedlono. Maria Skrzypecka i Zygmunt Baranowski zostali wywiezieni do Krakowskiego, a Marta Tomczak trafiła do miejscowości Błonawy ${ }^{26}$.

Ze szkoły w Cielcach nauczyciele sami powyjeżdżali w różne strony, chroniąc się przed represjami i aresztowaniami. Kronika wspomina o tym, że szkołę opuścili - Gronert, Kołodziejczak i Pawlak. Ci ostatni wyjechali do Łodzi. Uniknęli w ten sposób aresztowania, które nastąpiło w gminie 1 maja 1940 r. Aresztowanych wysyłano do obo-

\footnotetext{
19 P. Gołdyn, Sto lat oświaty w Stawsku 1915-2015, Kalisz 2015.

${ }^{20}$ Kronika szkoły w Biskupicach za lata 1926-1973, bp.

${ }^{21}$ Kronika szkoły w Budzisławiu Kościelnym za lata 1945-1994, bp.

22 Kronika szkoły w Ciążeniu za lata 1945-1966, bp

${ }^{23}$ Kronika szkoły w Golinie za lata 1945-1972, bp.

24 Kronika szkoły w Kotuni za lata 1945-1978, bp.

25 Kronika szkoły w Kramsku za lata 1945-1977, bp.

${ }^{26}$ Kronika szkoły w Lubstowie za lata 1945-1996, bp.
} 
zów koncentracyjnych w Dachau i Mauthausen. Kierownik szkoły uniknął aresztowania. Schronił się w pobliskiej Warcie. Jak zapisał w kronice: $W$ czerwcu przybytem po kryjomu do szkoty, zabratem akta, książki główne (ocen) i pieczęcie. Ukryłem to wszystko $w$ Warcie, gdzie przebywałem, kryjąc się przed władzami bezpieczeństwa aż do 20 października. Wtedy otrzymałem prace na poczcie $w$ charakterze listonosza wiejskiego ${ }^{27}$. Pracował tam jako doręczyciel listów do końca wojny.

Przed aresztowaniem uratowano także - dzięki znajomościom - Ignacego Ziębowicza, nauczyciela i kierownika szkoły w Dzierawach koło Koła. Został on aresztowany wraz z kilkoma innymi mieszkańcami wsi jako bezrobotny i miał zostać wywieziony do Niemiec. Wrócił jednakże do wioski i opisał takie oto zdarzenie, które zobaczył w swoim ogródku: Gdy ten powrócił, zastał w ogródku szkolnym kilkoro dzieci wyrywających warzywa. Wyrywano fasole z korzeniami. Wykopano 2 krzaki piwonii i rabarbar. Jak przykro byto patrzeć na te dzieci, które nie umiały uszanować pracy nauczyciela, które cieszyly się, że moga bezkarnie rabować. Oczywiście większa winę ponosza rodzice zezwalajacy na rabunek ${ }^{28}$. Ziębowicz do końca wojny pracował w firmie budowlanej poza wsią, musiał również opuścić mieszkanie w budynku szkolnym i zamieszkał w małej chatce w Dzierawach.

Co do problemu bezrobocia, to na wsiach bezrobotnymi pozostawiali przede wszystkim nauczyciele. Zamknięto im szkoły, a więc stracili możliwość pracy. Za takich uznał ich również sołtys wsi Kotunia, który przygotowywał dla urzędu gminy w Ciążeniu wykaz bezrobotnych. Na jego liście znaleźli się tylko i wyłącznie nauczyciele ${ }^{29}$.

W obozie karnym wojnę spędził kierownik szkoły w Górkach - Józef Jakubowski. Niestety nie są znane okoliczności jego aresztowania i osadzenia. Nie wiadomo również czy był to obóz karny czy koncentracyjny ${ }^{30}$.

Sporo nauczycieli zostało również zmobilizowanych z końcem sierpnia 1939 r. i brali oni udział w działaniach zbrojnych w czasie wojny obronnej. I tak np. z Borysławic dwóch nauczycieli broniło we wrześniu 1939 r. Ojczyny - Sobański i Władysław Ławniczka. Pierwszy z nich zginął pod Łęczycą, a drugi dostał się do niewoli ${ }^{31}$. Do wojska zmobilizowano także kierownika szkoły w Brdowie - M. Janowskiego, wrócił on jednak do Brodowa i 15 października 1939 r. podjął pracę na swoim dotychczasowym stanowi$\mathrm{sku}^{32}$. Zmobilizowano również kierownika szkoły w Janowie - Wacława Lasotę ${ }^{33}$. Do wojska został powołany kierownik szkoły w Kotuni oraz kilku nauczycieli3 ${ }^{34}$.

Zmobilizowano także kilku nauczycieli ze szkoły w Zagórowie, w tym kierownika szkoły Alfreda Pabla i Jana Piątkowskiego. Jako oficerowie wojska polskiego otrzymali

\footnotetext{
27 Kronika szkoły w Cielcach, za lata 1916-1955, bp.

${ }^{28}$ Kronika szkoły w Dzierawach za lata 1931-1976, s. 38.

29 Kronika szkoły w Kotuni za lata 1945-1978, bp.

30 Kronika szkoły w Górkach za lata 1945-54, bp.

${ }^{31}$ Kronika szkoły w Borysławicach Kościelnych za lata 1945-1984, bp.

32 Kronika szkoły w Brodowie za lata 1945-1996, bp.

33 Kronika szkoły w Janowie za lata 1945-1983, bp.

${ }^{34}$ Kronika szkoły w Kotuni za lata 1945-1978, bp.
} 
tylko część poborów za wrzesień, a ściślej mówiąc tylko jedną czwartą. Więcej, bo połowę dostali chorążowie i podchorążowie - w tym przypadku byli to nauczyciele: Wojciech Maśliński i Stanisław Jakubowski ${ }^{35}$.

Nie wszystkim nauczycielom dane było przeżyć wojnę. Spora ich grupa zginęła rozstrzelana lub zginęła w obozach koncentracyjnych, a największą grupę stanowili pedagodzy z powiatu tureckiego. 10 listopada 1939 r. śmierć przez rozstrzelanie w Koninie poniósł nauczyciel szkoły powszechnej z Grodźca - Józef Pęcherski. Miał on według opisu kronikarskiego być zadenuncjowany przez miejscowego pastora ewangelickiego Ulbrycha i nauczyciela ze szkoły niemieckiej w Starym Borowcu - E. Hermana. Ten ostatni zresztą przejął kierownictwo szkoły. Zwolnił od razu dwoje polskich nauczycieli - Helenę Pęcherską i Irenę Podczaską. Pracę natomiast otrzymali S. Walicki, A. Legowska i J. Lipkówna ${ }^{36}$.

Wspomniany tu Walicki pracował przed wojną w szkole w Lipicach, musiał jednakże wyjechać, ale kiedy wrócił nie miał możliwości zatrudnienia w swej macierzystej placówce. Zatrudniono go w Grodźcu, jednakże w konsekwencji został wysiedlony do Tarnowa. Przyczynił się do tego niemiecki komisarz szkolny na gminę Grodziec, którym był „nowy” kierownik grodzieckiej szkoły, Edmund Hermann. Jeśli chodzi o postawę tego ostatniego wobec polskich nauczycieli, swoich dawnych kolegów, to zachowały się zupełnie skrajne opinie. Wcześniej, jak wspomniano miał się przyczynić do śmierci polskiego nauczyciela, z kolei na kartach kroniki szkolnej w Lipicach można przeczytać taką oto informację: ,, Schulkomisarem” na tut. gminę byt byty polski nauczyciel z Borowca hitlerowiec Hermann Edmund - zachowujac się wobec bytych swych kolegów nauczycieli, zupetnie przyzwoicie. Wysiedlenie p. Walickiego byto jego robota, ale podobno zrobit to by uratować go przed pewna śmiercia, której domagali się miejscowi Niemcy, za jego manifestacyjne przemówienie antyniemieckie ${ }^{37}$.

Niemcy niezwykle szybko przystąpili do eksterminacji nauczycieli na terenie powiatu tureckiego (powiat ten przynależał administracyjnie do rejencji łódzkiej, kolski i koniński były w rejencji inowrocławskiej). Aresztowania, wysiedlania i wywózki do obozów koncentracyjnych rozpoczęły się już na początku listopada 1939 r. Ze szkoły powszechnej nr $1 \mathrm{w}$ Turku do obozu w Mauthausen trafili Czesław Kozłowski i Józef Turek. Do Generalnego Gubernatorstwa wysiedlono rodziny nauczycielskie: Janowiczów, Stachów, Robakiewiczów, Kozłowskich i Kukulskich ${ }^{38}$.

Z kolei w kronice szkoły w Grzymiszewie zapisano, że ofiarą aresztowań prowadzonych przez Niemców padł kierownik tamtejszej szkoły - Lucjan Zieliński39. Trafił on później do obozu koncentracyjnego w Dachau, gdzie stracił życie ${ }^{40}$. Kronika szkolna

\footnotetext{
35 Kronika szkoły w Zagórowie za lata 1945-1983, s. 10.

${ }^{36}$ Kronika szkoły w Grodźcu za lata 1945-1976, bp.

37 Kronika szkoły w Lipicach za lata 1945-1984, bp.

${ }^{38}$ Kronika szkoły powszechnej nr 1 w Turku za lata 1945-1987, bp.

39 Kronika szkoły w Grzymiszewie za lata 1945-1951, bp.

${ }^{40}$ M. Walczak, Nauczyciele wielkopolscy w latach wojny i okupacji 1939-1945, Poznań 1974, s. 170-172.
} 
w Kotuni informuje o pierwszej ofierze władz hitlerowskich wśród nauczycieli z regionu słupeckiego. Był to nauczyciel ze Smarzewa - Aleksander Hofman ${ }^{41}$.

W obozie koncentracyjnym w Gusen zginął kierownik szkoły w Wyszynie - Tadeusz Posada. Było to w roku $1941^{42}$. O aresztowaniu i śmierci nauczyciela kierownika szkoły we Władysławowie kronikarz umieścił taką oto notatkę: Pracę Kusiaka i grona przerwata wojna w 1939 r. a aresztowanego Kusiaka wywieziono do koncentracyjnego lagru w Dachau, a potem do Gusen, gdzie w ciężkich męczarniach zmart, zostawiajac żonę i troje dzieci $i^{43}$.

Straty osobowe w stanie nauczycielskim w powiecie tureckim były niezwykle duże. W kronice szkoły powszechnej nr $1 \mathrm{w}$ Turku napisano: Odwieczny wróg naszego narodu wymordowat $w$ obozach koncentracyjnych około 80-ciu nauczycieli z naszego powiatu. Spośród wywiezionych do obozów śmierci wróciło tylko trzech kolegów - naocznych świadków tej strasznej tragedii. Ogromna większość szkót straciła od 1 do 6 nauczycieli ${ }^{44}$.

Aresztowano także kierownika szkoły w Kazimierzu Biskupim - Eugeniusza Gajewskiego i trzymano go w charakterze zakładnika. Razem z nim przetrzymywano miejscowego proboszcza i sołtysa wsi. Według relacji pilnowani byli przez specjalny oddział żołnierzy, a za pośrednictwem tłumacza wyjaśniono im, że mogą zostać rozstrzelani, gdy zaistnieje taka potrzeba. Na przykład w odwecie za śmierć niemieckiego żołnierza. Od czasu do czasu stychać, odbywała się strzelanina. Wtedy przychodzit do aresztowanych tlumacz i oznajmiat, że w Kazimierzu i okolicy zostaty unieszkodliwione bandy. Odchodzac pocieszat, że aresztowani moga jeszcze spać spokojnie, gdyż nie została wyrzadzona żadna krzywda żolnierzowi niemieckiemu. Rano zwykle dochodzity wiadomości, że w lesie ktoś został zabity. Po uptywie miesiaca aresztowani zostali zwolnieni ${ }^{45}$.

Niezwykle rzadko pojawiały się informacje o prowadzeniu przez nauczycieli tajnego nauczania. Z kronik szkoły w Kawnicach można dowiedzieć się, że taką działalność prowadziła Bronisława Zborowska, która nie wyjechała i nie została zaaresztowana. Wspomagała ją w tym również Maria Rogowska ${ }^{46}$.

Ci nauczyciele zagórowscy, którzy zostali na miejscu, w mniejszym lub większym stopniu podjęli się tajnego nauczania. Jednakże w wakacje w 1940 r. wszyscy zostali wezwani na przesłuchanie. Przesłuchiwano każdego z osobna, ale wszyscy stanowczo zaprzeczyli, jakoby prowadzili działalność edukacyjną. Wśród nauczających należy wymienić: Irenę Orchowską, Janinę Ulatowską, Marię Wróblewską, Józefę Wysokowską, Stanisława Jakubowskiego i Jana Piątkowskiego ${ }^{47}$.

Jeszcze rzadziej można przeczytać o nauczycielach, którzy współpracowali z okupantem. Informacja taka znalazła się m.in. na stronach kroniki szkolnej z Kazimierza Bisku-

\footnotetext{
${ }^{41}$ Kronika szkoły w Kotuni za lata 1945-1978, bp.

42 Kronika szkoły w Wyszynie za lata 1945-1999, bp.

${ }^{43}$ Kronika szkoły we Władysławowie za lata 1945-1971, bp.

${ }^{44}$ Kronika szkoły powszechnej nr 1 w Turku za lata 1945-1987, bp.

${ }^{45}$ Kronika szkoły w Kazimierzu Biskupim za lata 1945-1984, bp.

46 Kronika szkoły w Kawnicach za lata 1945-1972, bp.

47 Kronika szkoły w Zagórowie za lata 1945-1983, s. 18.
} 
piego. Kiedy odebrano kierownictwo Eugeniuszowi Gajewskiemu, Niemcy powierzyli je Pelagii Ambroziak, o której po wojnie napisano: Obywatelka Ambroziak cały czas okupacji niemieckiej pracowała $w$ różnych instytucjach niemieckich, a ostatnio $w$ urzędzie gminnym. Jak twierdzi miejscowa ludność, ob. Pelagia Ambroziak swoim zachowaniem i stosunkiem do Niemców w czasie okupacji nie przyniosła zaszczytu szkole, zawodowi nauczycielskiemu, jak również narodowi polskiemu ${ }^{48}$. Trudno dziś z perspektywy czasu oceniać postawę wspomnianej nauczycielki. Z pewności należałoby w tym kierunku przeprowadzić osobne badania, aby potwierdzić lub podważyć powyższe zarzuty zapisane na kartach kroniki szkolnej.

Także w Kramsku nauczyciele byli ulegli wobec okupantów. Kronikarz szkolny tak opisał tę sytuację: stabe charaktery ulegaja wpływom niemieckim, i tak Roszko [nauczyciel] deklaruje sie jako Niemiec $i$ dostaje prace $w$ zarzadzie gminnym, gdzie juz pracuje naucz. Ukrainiec z Patrzykowa Andrejko Piotr. Żona Roszki Wiktoria wychowuje dzieci Jerzego i Zygfryda w duchu niemieckim, posyłajac ich do szkoły niemieckiej ${ }^{49}$.

Kronikarz kramski, odtwarzając losy nauczycieli kramskich, wspomina także o nauczycielach, którzy przybyli na teren gminy Kramsk. Wymienia tu nauczycielkę Walczkową, która pojawiła się wraz z rodziną i od czasu do czasu, aby się utrzymać pracowała w gospodarstwie Lewandowskiego. Wymienia także katechetkę z Milina - Podczaską Irenę, która pracowała w gminie, ale podpisała „Leistunglistę” (sic!). Z kolei o nauczycielce Kublinowej pisał, że chciała być wpisana na Volklistę i dopytywała się Roszkowej, jak to zrobić. Nauczycielka Lupa pracowała przez długi czas przy wale jako magazynierka, ale wymawiając się stanem zdrowia otrzymała inną posadę, miała pod zarządem sklep w Wysokiem, a potem w Świętem ${ }^{50}$.

Wielu z tych nauczycieli przeżyło wojnę i już od stycznia 1945 r. podjęło się instauracji szkolnictwa po zawierusze wojennej. Przetrwali, często $w$ bardzo trudnych warunkach, pod terrorem niemieckiego zwierzchnictwa, lecz z niegasnaca nigdy nadzieja na lepsze jutro, aż do chwili oswobodzenia Polski ${ }^{51}$.

Podsumowując, należy stwierdzić, że powyższe rozważania są elementem wprowadzenia do tematu. Z pewnością badania te należałoby kontynuować z wykorzystaniem większej liczby kronik. Niezwykle interesującym byłoby również porównanie pracy nauczycieli, właśnie w oparciu o kroniki, z różnych zakątków okupowanej Polski. Dałoby to ciekawy obraz wojennej rzeczywistości. Powyższe zatem rozważania można potraktować jako wstęp i postulat badawczy.

\footnotetext{
${ }^{48}$ Kronika szkoły w Kazimierzu Biskupim za lata 1945-1984, bp.

49 Kronika szkoły w Kramsku za lata 1945-1977, bp.

${ }^{50}$ Kronika szkoły w Kramsku za lata 1945-1977, bp.

${ }^{51}$ Kronika szkoły w Kłodawie za lata 1931-1951, bp.
} 


\section{Bibliografia}

\section{Źródła}

Kronika Szkoły Podstawowej w Białej Panieńskiej. cz. II.

Kronika Szkoły w Grzymiszewie za lata 1945-1951.

Kronika szkoły w Kucharach Kościelnych za lata 1949-1992.

Kronika szkoły w Tuliszkowie za lata 1945-1959.

Kronika szkoły w Biskupicach za lata 1926-1973.

Kronika szkoły w Budzisławiu Kościelnym za lata 1945-1994.

Kronika szkoły w Zagórowie za lata 1945-1983.

Kronika szkoły w Kłodawie za lata 1931-1951.

Kronika szkoły w Modle Królewskiej za lata 1912-1948.

Kronika szkoły w Kotuni za lata 1945-1978.

Kronika szkoły w Brodowie za lata 1945-1996.

Kronika szkoły w Dzierawach za lata 1931-1976.

Kronika szkoły w Ciążeniu za lata 1945-1966.

Kronika szkoły w Golinie za lata 1945-1972.

Kronika szkoły w Kramsku za lata 1945-1977.

Kronika szkoły w Lubstowie za lata 1945-1996.

Kronika szkoły w Cielcach, za lata 1916-1955.

Kronika szkoły w Górkach za lata 1945-54.

Kronika szkoły w Borysławicach Kościelnych za lata 1945-1984.

Kronika szkoły w Brodowie za lata 1945-1996.

Kronika szkoły w Janowie za lata 1945-1983.

Kronika szkoły w Grodźcu za lata 1945-1976.

Kronika szkoły w Lipicach za lata 1945-1984.

Kronika szkoły powszechnej nr $1 \mathrm{w}$ Turku za lata 1945-1987.

Kronika szkoły w Wyszynie za lata 1945-1999.

Kronika szkoły we Władysławowie za lata 1945-1971.

Kronika szkoły w Kazimierzu Biskupim za lata 1945-1984.

Kronika szkoły w Kawnicach za lata 1945-1972.

\section{Opracowania}

Gołdyn P., Kronika szkolna jako nie(d)ocenione źródło do dziejów oświaty regionalnej, w: Badania historyczne w pedagogice. Konteksty źródlowe, red. W. Szulakiewicz, Torun 2015.

Gołdyn P., Watki biograficzne nauczycieli w kronikach szkolnych. Przykład Wielkopolski wschodniej, w: Przedmiot, źródla i metody badań w biografii, red. R. Skrzyniarz, L. Dziaczkowska, D. Opozda, Lublin 2016.

Gołdyn P., Sto lat oświaty w Stawsku 1915-2015, Kalisz 2015.

Walczak M., Nauczyciele wielkopolscy w latach wojny i okupacji 1939-1945, Poznań 1974. 